\title{
SHALLOW GROUND-WATER QUALITY IN THE PLATTE RIVER VALLEY ALLUVIUM, NEBRASKA, OCTOBER-NOVEMBER 1997
}

\section{SIGNIFICANT FINDINGS}

Nitrate was detected in samples from 25 of 27 wells; concentrations in 6 of the samples exceeded the U.S. Environmental Protection Agency maximum contaminant level of $\mathbf{1 0}$ milligrams per liter for drinking water.

Arsenic was detected in samples from 23 of 27 wells, but all concentrations were below the U.S. Environmental Protection Agency maximum contaminant level of 50 micrograms per liter.

Radon was detected in samples from all 27 wells.

No volatile organic compounds were detected with concentrations greater than the method detection limit.

\section{INTRODUCTION}

Contamination of surface and ground water from nonpoint sources is a national issue. Examples of nonpoint-source contaminants from agricultural activities are pesticides (fungicides, herbicides, and insecticides), sediments, and nutrients (nitrate and phosphorus). The Platte River Valley in Nebraska (fig. 1) is a flat lowland area underlain primarily by unconsolidated alluvial deposits of Quaternary age that have a maximum thickness of less than $100 \mathrm{ft}$ (feet) and consist mostly of gravel, sand, silt, and clay (Gutentag and others, 1984, p. 9). These deposits are the single most important source of water for public supply for Nebraska's largest cities including Omaha, Lincoln, Grand Island, and Kearney. These deposits pro-

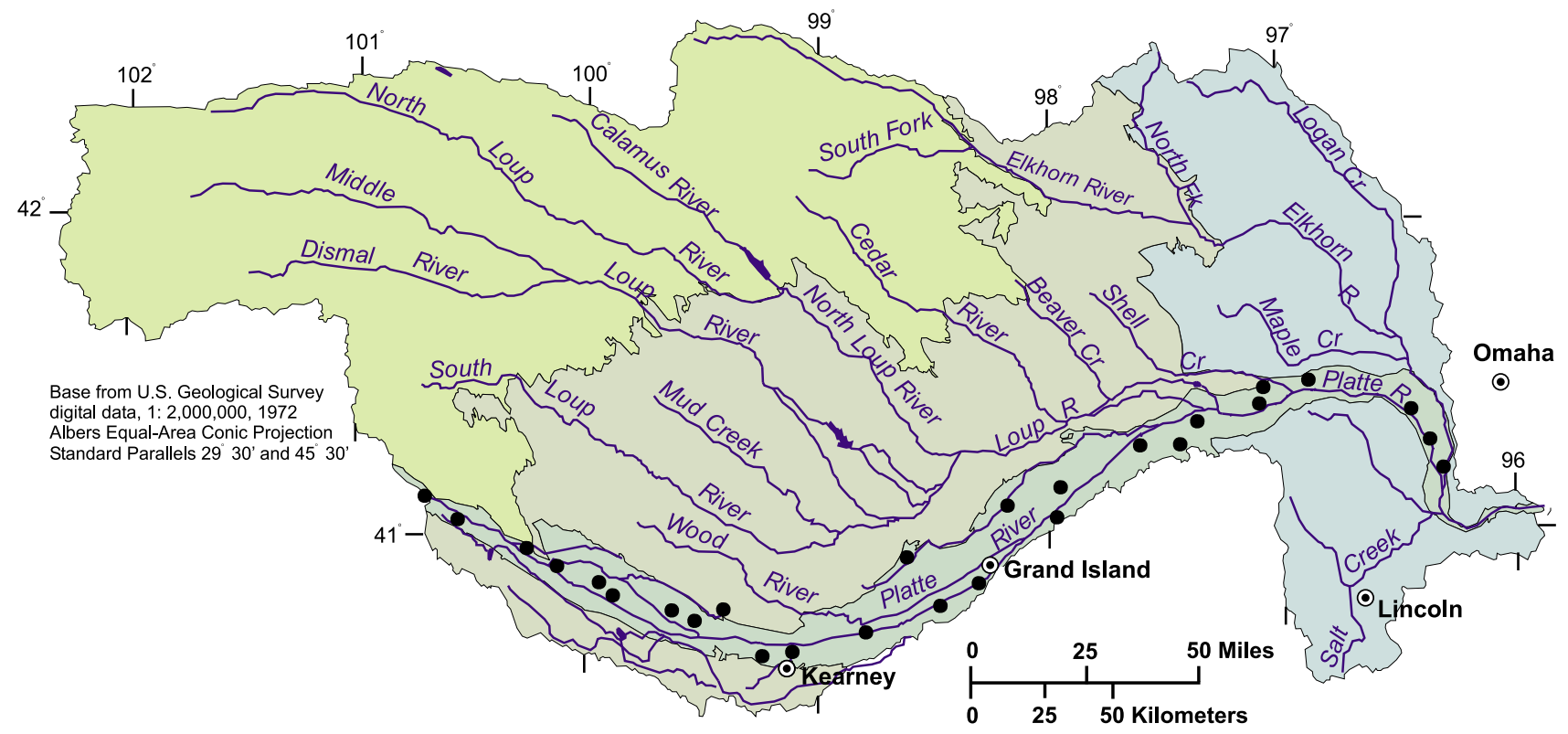

\section{EXPLANATION}

Sandhills

Loess Hills

Glaciated Area

Platte River Valley

- Sampled well

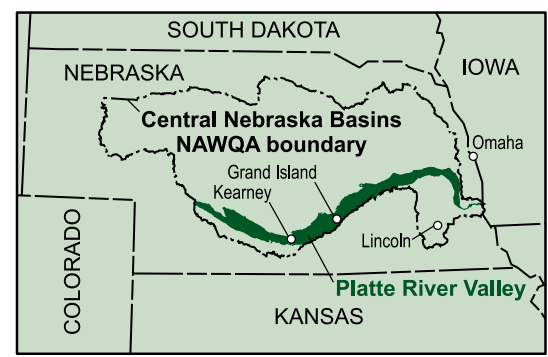

Figure 1. Location and sampled wells of the Platte River Valley alluvium in the Central

Nebraska Basins study unit. 
vide about $117 \mathrm{Mgal} / \mathrm{d}$ (million gallons per day), nearly 50 percent of the total daily ground-water production for Nebraska (Nebraska Natural Resources Commission, 1994). The Platte River Valley also includes permeable soils, shallow groundwater levels, and extensive areas of irrigated land used to grow corn. These conditions increase the vulnerability of the ground water to agricultural contaminants.

The U.S. Geological Survey's (USGS) National Water Quality Assessment (NAWQA) Program is designed to describe the status and trends in the quality of the Nation's surface- and ground-water resources and to provide a sound understanding of the natural and human factors affecting the quality of these resources. Important components of the program are assessments of more than 50 major river basins and aquifers, called study units. The Central Nebraska Basins study unit (CNBR) was among the set of 20 study-unit investigations begun in 1991. The
Central Nebraska Basins comprise sandhills, loess hills, and glaciated areas adjacent to the valley of the Platte River, the main river draining the study unit (fig. 1). This study provides data regarding water quality in Platte River Valley alluvium that was not included in the previous study (Frenzel and others, 1998).

In 1997, 27 wells completed in the Platte River Valley alluvium were randomly selected and sampled as part of a CNBR Study (Sub)-Unit Survey (SUS). Quality of shallow ground-water (water in alluvial deposits) of the Platte River Valley is described in this report. A total of 27 wells (fig. 1) were sampled. Well depths ranged from 12 to $124 \mathrm{ft}$ and the water table ranged from about 2.9 to $31 \mathrm{ft}$ below land surface. Physical properties of specific conductance, $\mathrm{pH}$, and dissolved oxygen were measured on-site at the time of sample collection. Water was collected from the wells using nationally consistent sampling methods developed as part of the NAWQA program, and was analyzed by the U.S. Geological Survey's National Water Quality Laboratory in Arvada, Colorado for the presence of major ions, nutrients, trace elements, radionuclides, volatile organic compounds (VOCs), and pesticides. The following is a description of the quality of the water in the Platte River Valley alluvium based on the results of this SUS.

\section{GROUND-WATER QUALITY}

The physical properties of the shallow ground water in the Platte River alluvial aquifer revealed some variation. The specific conductance values ranged from 293 to $2,870 \mu \mathrm{S} / \mathrm{cm}$ (microsiemens per centimeter at 25 degrees Celsius) with a median of $721 \mu \mathrm{S} / \mathrm{cm}$. The $\mathrm{pH}$ values ranged from 6.2 to 7.8 with a median of 7.2. The U.S. Environmental Protection Agency (USEPA) Secondary Maximum Contaminant Level (SMCL) for $\mathrm{pH}$ is a range of 6.5 to 8.5 (U.S. Environmental Protection Agency, 1996). An SCML is a standard set for aesthetic purposes and is

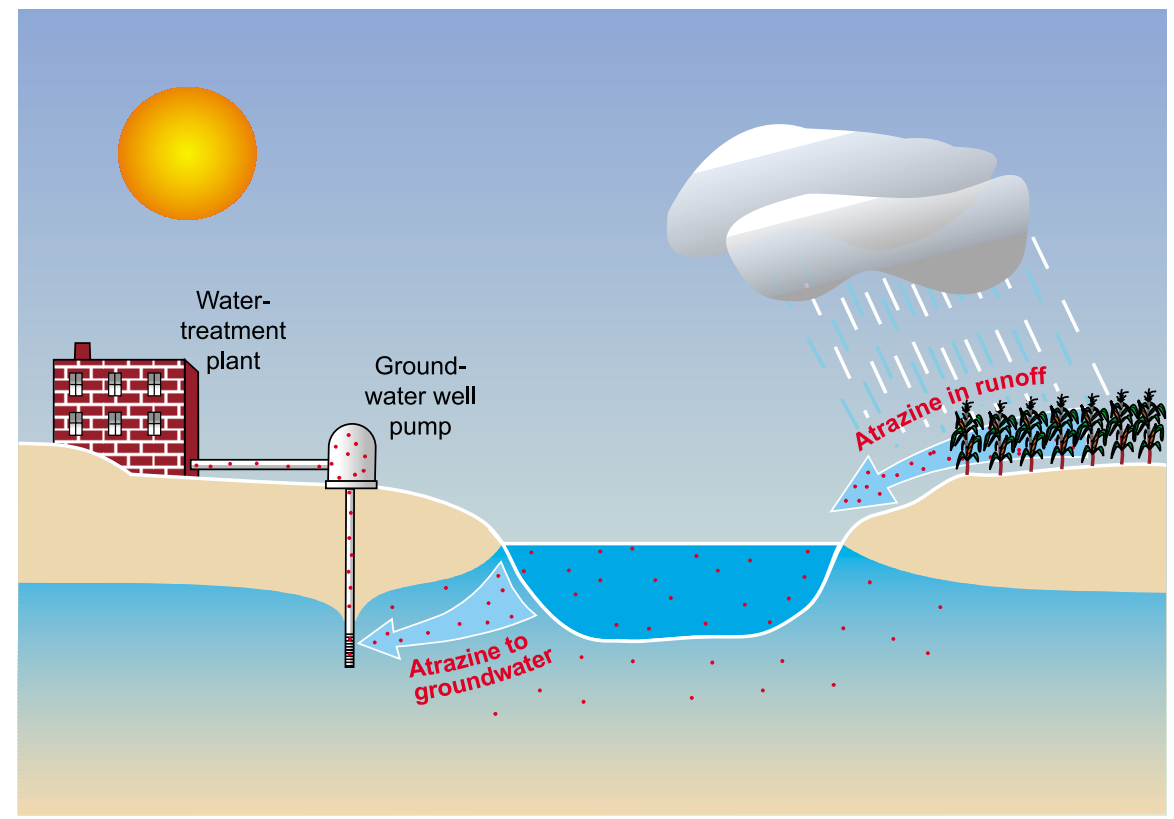

Figure 2. Atrazine movement from the Platte River through alluvial aquifers (Frenzel and others, 1998). 
not health-based. Dissolved-oxygen concentrations ranged from 7.9 to $0.14 \mathrm{mg} / \mathrm{L}$ (milligrams per liter) with a median of $0.62 \mathrm{mg} / \mathrm{L}$.

Results of analyses for the selected constituents are summarized in table 1 . No VOC concentrations greater than the method detection limit were found in water samples analyzed for 55 VOCs.

\section{MAJOR IONS}

The major-ion concentrations, including calcium, magnesium, sodium, potassium, sulfate, chloride, fluoride, and silica, were typical of the Platte River Valley (Zelt and Jordan, 1993). Sulfate in drinking water currently has an SMCL of $250 \mathrm{mg} / \mathrm{L}$, based on aesthetic effects (taste and odor). The concentrations of sulfate ranged from 18 to $941 \mathrm{mg} / \mathrm{L}$ with a median concentration of $68 \mathrm{mg} / \mathrm{L}$. Five of the 27 sulfate concentrations exceeded the SMCL.

\section{NUTRIENTS}

The nutrients nitrogen and phosphorus commonly occur naturally in ground water, but elevated concentrations may be from the influence of human activity. Nitrite plus nitrate (table 1), herein referred to as nitrate, has a USEPA-established maximum contaminant level (MCL) for drinking water of $10 \mathrm{mg} / \mathrm{L}$ as nitrogen. In this study, 6 of the 27 ground-water samples collected exceeded this level. Concentrations ranged from 0.05 to $48 \mathrm{mg} / \mathrm{L}$, with a median of $2.9 \mathrm{mg} / \mathrm{L}$ (table 1). Previous evaluations of nitrate concentrations in the Platte Valley indicated that the major source of the nitrate is from application of fertilizers on the land surface (Spalding, 1975; Exner and Spalding, 1976; Engberg and Spalding, 1978) and that the median concentrations in shallow ground water were larger than those in deep ground water

Table 1. Concentrations of selected chemical constituents and method detection limits in ground-water samples collected from 27 wells in the Platte River Valley, Nebraska, October - November 1997

[mg/L, milligrams per liter; $\mu \mathrm{g} / \mathrm{L}$, micrograms per liter; $\mathrm{pCi} / \mathrm{L}$, picocuries per liter; <, less than]

\begin{tabular}{|c|c|c|c|c|c|}
\hline \multirow[b]{2}{*}{ Chemical constituents } & \multirow{2}{*}{$\begin{array}{l}\text { Number of } \\
\text { detections }\end{array}$} & \multirow{2}{*}{$\begin{array}{l}\text { Method } \\
\text { detection } \\
\text { limit }\end{array}$} & \multicolumn{3}{|c|}{ Concentration } \\
\hline & & & Minimum & Median & Maximum \\
\hline \multicolumn{6}{|c|}{ Major ions (mg/L) } \\
\hline Calcium & 27 & 0.02 & 43 & 81 & 298 \\
\hline Magnesium & 27 & .004 & 5.5 & 20 & 65 \\
\hline Sodium & 27 & .10 & 5.8 & 35 & 396 \\
\hline Potassium & 27 & .10 & 3.8 & 9.0 & 57 \\
\hline Sulfate & 27 & .10 & 18 & 68 & 941 \\
\hline Chloride & 27 & .10 & 1.9 & 14 & 57 \\
\hline Fluoride & 27 & .10 & .10 & .39 & 1.1 \\
\hline Silica & 27 & .10 & 19 & 38 & 58 \\
\hline \multicolumn{6}{|c|}{ Dissolved nutrients (mg/L) } \\
\hline Nitrogen, nitrite & 10 & .01 & .02 & .06 & .17 \\
\hline Nitrogen, nitrite plus nitrate & 25 & .05 & .05 & 2.9 & 48 \\
\hline Nitrogen, ammonia & 7 & .02 & .04 & .02 & .24 \\
\hline Nitrogen, ammonia plus organic & 15 & .10 & .13 & .25 & .67 \\
\hline Phosphorus & 25 & .01 & .01 & .11 & .86 \\
\hline Phosphorus, orthophosphate & 25 & .01 & .02 & .15 & .90 \\
\hline \multicolumn{6}{|c|}{ Trace elements $(\mu \mathrm{g} / \mathrm{L})$} \\
\hline Arsenic & 23 & 1 & 1 & 6 & 24 \\
\hline \multicolumn{6}{|c|}{ Radionuclides } \\
\hline Radon $222(\mathrm{pCi} / \mathrm{L}))$ & 27 & 70 & 132 & 293 & 733 \\
\hline Uranium $(\mu \mathrm{g} / \mathrm{L})$ & 23 & .30 & 2.45 & 18.1 & 174 \\
\hline \multicolumn{6}{|c|}{ Pesticides $(\mu \mathrm{g} / \mathrm{L})$} \\
\hline Atrazine & 21 & .004 & .004 & .180 & .690 \\
\hline Metolachlor & 10 & .004 & .004 & .006 & .300 \\
\hline
\end{tabular}

(Helgesen and others, 1994). Dissolved-phosphorus concentrations in samples collected for this study generally were low (table 1). Two of the 27 samples were below the detection limits. The range was from less than the detection limit $(0.01 \mathrm{mg} / \mathrm{L})$ to $0.86 \mathrm{mg} / \mathrm{L}$, and the median concentration was $0.11 \mathrm{mg} / \mathrm{L}$.

\section{TRACE ELEMENTS}

Analyses of ground-water samples for trace elements were examined to determine whether or not the
MCLs were exceeded for any of the following constituents: antimony, arsenic, barium, beryllium, cadmium, chromium, lead, and selenium. For this study, no trace elements exceeded the MCLs.

Recently, the National Research Council (1999) recommended lowering the current MCL for arsenic in drinking water of $50 \mu \mathrm{g} / \mathrm{L}$ (micrograms per liter) to a proposed $10 \mu \mathrm{g} / \mathrm{L}$, citing risks for developing bladder and other cancers. The World Health Organization (1999) provisional guideline for arsenic in drinking water is $10 \mu \mathrm{g} / \mathrm{L}$. The USEPA will propose a new, and likely lower, 
arsenic MCL during 2000

(U.S. Environmental Protection

Agency, 2000). Arsenic was detected in 23 of the 27 samples collected for this study. No concentrations exceeded the current MCL of $50 \mu \mathrm{g} / \mathrm{L}$, although three samples exceeded $10 \mu \mathrm{g} / \mathrm{L}$.

\section{RADIONUCLIDES}

Radon is a product of the radioactive decay of uranium that is soluble in water and organic liquids, but readily degasses from water into the atmosphere as a result of its low partial pressure in air. Radon from tap water is a smaller source but when released into the air from household water uses increases the risk of lung cancer over the course of one's lifetime (U.S. Environmental Protection Agency, 1999). There is currently no federally enforced drinking-water standard for radon. Radon was detected in all 27 ground-water samples. Radon concentrations ranged from 132 to $733 \mathrm{pCi} / \mathrm{L}$ (picocuries per liter) with a median radon concentration of $293 \mathrm{pCi} / \mathrm{L}$.

Uranium is a naturally occurring radioactive element that is present in igneous rocks, sedimentary ore bodies, and phosphate rocks and their weathered products (Maynard, 1983). It has been suggested that higher uranium concentrations throughout the Platte River Valley occur as a result of the weathering of crystalline and sedimentary rocks (Spalding and Druliner, 1981). Uranium was detected in 23 of the 27 ground-water samples (table 1). Uranium concentrations ranged from 2.45 to $174 \mu \mathrm{g} / \mathrm{L}$ with a median of $18.1 \mu \mathrm{g} / \mathrm{L}$.

\section{PESTICIDES}

Samples were analyzed for pesticides, including insecticides, herbicides, and fungicides. Only two of the
44 pesticides for which samples were analyzed - atrazine and metolachlor-were detected (table 1). Atrazine was detected in 21 of the 27 samples (table 1). The concentrations of atrazine ranged from 0.004 to $0.690 \mu \mathrm{g} / \mathrm{L}$, with a median concentration of $0.180 \mu \mathrm{g} / \mathrm{L}$. Metolachlor was detected in 10 of the 27 samples, with a median value of $0.006 \mu \mathrm{g} / \mathrm{L}$. Concentrations of pesticides may be a concern in water supplies that rely on shallow wells where the alluvial aquifer is hydraulically connected to nearby streams (see following section).

\section{SURFACE-WATER/GROUND- WATER INTERACTION}

An important hydrologic process in the Platte River Valley is surfacewater/ground-water interaction (Huntzinger and Ellis, 1993). Ground water in the alluvial deposits has a direct hydraulic connection with the Platte River (Steele and Verstraeten, 1999; Verstraeten and others, 1999); thus, ground-water gradients and water quality are affected by flows in the river (fig. 2), and by diversions and return flows of surface water used for irrigation and power generation. The results of studies using atrazine in the Platte River as a tracer (Duncan and others, 1991; Blum and others, 1993; Verstraeten and others, 1999) revealed how dissolved constituents moved from the Platte River through the alluvium in nearby observation and municipal wells. Travel times as short as 5 days have been determined. This information helps water-resources managers to protect the quality of the drinking water supplied to the cities that rely on alluvium in the Platte River as a source.

_By James M. Parnell

\section{SELECTED REFERENCES}

Blum, D.A., Carr, J.D., Davis, R.K., and Pederson, D.T., 1993, Atrazine in a stream-aquifer system-Transport of atrazine and its environmental impact near Ashland, Nebraska: Ground Water Monitoring and Remediation, v. 13, no. 2, p. 125-133.

Boyd, R.A., 1996, Distribution of nitrate and orthophosphate in selected streams in central Nebraska: Water Resources Bulletin, v. 32, no. 6 , p. 1247-1257.

Duncan, D., Pederson, D.T., Shepard, T.R., and Carr, J.D., 1991, Atrazine used as a tracer of induced recharge: Groundwater Monitoring Review, v. 11, no. 4, p. 144-150.

Engberg, R.A., and Spalding, R.F., 1978, Groundwater quality atlas of Nebraska: Lincoln, University of Nebraska-Lincoln, Conservation and Survey Division Resource Atlas No. 3, 39 p.

Exner, M.E., and Spalding, R.F., 1976, Groundwater quality of the central Platte region, 1974: Lincoln, University of NebraskaLincoln, Conservation and Survey Division Resource Atlas No. 2, 47 p.

Frenzel, S.A., Swanson, R.B., Huntzinger, T.L., Stamer, J.K., Emmons, P.J., and Zelt, R.B., 1998, Water quality in the central Nebraska Basins, Nebraska, 1992-95: U.S. Geological Survey Circular 1163, 33 p.

Gutentag, E.D., Heimes, F.J., Krothe, N.C., Luckey, R.R., and Weeks, J.B., 1984, Geohydrology of the High Plains aquifer in parts of Colorado, Kansas, Nebraska, New Mexico, Oklahoma, South Dakota, Texas, and Wyoming: U.S. Geological Survey Professional Paper 1400-B, 63 p. 
Helgesen, J.O., Zelt, R.B., and Stamer, J.K., 1994, Nitrogen and phosphorus in water as related to environmental setting in Nebraska: Water Resources Bulletin, v. 30, no. 5, p. 809-822.

Huntzinger, T.L., 1991, National Water-Quality Assessment Program - The Central Nebraska Basins: U.S. Geological Survey Open-File Report 91-97, 2 p.

Huntzinger, T.L., and Ellis, M.J., 1993, Central Nebraska River Basins, Nebraska: Water Resources Bulletin, v. 29, no. 4, p. 533-574.

Huntzinger, T.L. and Stamer, J.K., 1996, Science for a sustainable future of the Great PlainsWater-quality assessment in central Nebraska: U.S. Geological Survey Open File Report 96-140, 4 p.

Madison, R.J., and Brunett, J.O., 1985, Overview of the occurrence of nitrate in ground water of the United States, in National water summary 1984-Hydrologic events, selected water-quality trends, and ground-water resources: U.S. Geological Survey Water-Supply Paper 2275, p. 93-105.

Maynard, J.B., 1983, Geochemistry of sedimentary ore deposits: New York, Springer-Verlag, p. 147180.

National Research Council, 1999, Arsenic in drinking water: Washington, D.C., National Academy Press, 273 p.

Nebraska Natural Resources Commission, 1994, Estimated water use in Nebraska, 1990: Lincoln, Nebraska Natural Resources Commission, 58 p.
Nguyen, Q.M., and Gilliland, M.W., 1985, A surface water - groundwater interaction model for the Platte River well field of the City of Grand Island [Nebraska]: Omaha, University of NebraskaLincoln, Department of Civil Engineering, $179 \mathrm{p}$.

Pederson, D.T., 1994, Fundamentals of groundwater contamination: University of Nebraska-Lincoln, Conservation and Survey Division, Educational Circular 11, $18 \mathrm{p}$.

Spalding, R.F., 1975, Effects of land use and river seepage on groundwater quality in Hall County, Nebraska: Nebraska Water Survey Paper No. 38, 95 p.

Spalding, R.F., and Druliner, A.D., 1981, Ground-water uranium concentrations-How high is high?: Studies in Environmental Science, v. 17, 6 p.

Squillace, P.J., Caldwell, J.P., Schulmeyer, P.M., and Harvey, C.A., 1996, Movement of agricultural chemicals between surface water and ground water, lower Cedar River Basin, Iowa: U.S. Geological Survey Water-Supply Paper 2448, 59 p.

Steele, G.V. and Verstraeten, I.M., 1999, Effects of pumping collector wells on river-aquifer interaction at Platte River Island near Ashland, Nebraska, 1998: U.S. Geological Survey Water Resources Investigations Report 99-4161, 6 p.

U.S. Department of Health and Human Services, 1998, Toxicological profile for arsenic: Athens, Georgia, U.S. Department of Health and Human Services, Agency for Toxic Substances and Disease Registry, 349 p.
U.S. Environmental Protection Agency, 1996, Drinking Water Regulations and Health Advisories: Washington, D.C., U.S. Environmental Protection Agency, Office of Water, $14 \mathrm{p}$. 1999, Proposed Radon in Drinking Water Rule: Washington D.C., U.S. Environmental Protection Agency, Office of Water, EPA 815-F-99-006, 6 p. 2000 , Drinking water priority rulemaking - arsenic: accessed on 4/5/00 at URL http:// www.epa.gov/OGWDW/ars/ arsenic.html.

Verstraeten, I.M., Carr, J.D., Steele, G.V., Thurman, E.M., Bastin, K.C., and Dormedy, D.F., 1999, Surface water-ground water interaction- herbicide transport into municipal collector wells: Journal of Environmental Quality, v. 28 , no. 5, p. 1396-1405.

Welch, A.H., Watkins, S.A., Helsel, D.R. and Focazio, M.J., 2000, Arsenic in ground-water resources of the United States: Fact Sheet FS-063-00, 4 p.

Winter, T.C. Harvey, J.W., Franke, O.L., and Alley, W.H., 1998, Ground water and surface water-A single resource: U.S. Geological Survey Circular $1139,79 \mathrm{p}$.

World Health Organization, 1999, Arsenic in drinking water-Fact Sheet 210 , accessed on $4 / 5 / 00$ at URL http://www.who.int/inf-fs/ en/fact $210 . h t m l$.

Zelt, R.B., and Jordan, P.R., 1993, Water-quality assessment of the Central Nebraska Basins-Summary of data for recent conditions through 1990: U.S. Geological Survey Open-File Report 93-422, 178 p. 
For more information, contact:

District Chief

U.S. Geological Survey

Federal Building, Room 406

100 Centennial Mall North

Lincoln, Nebraska 68508

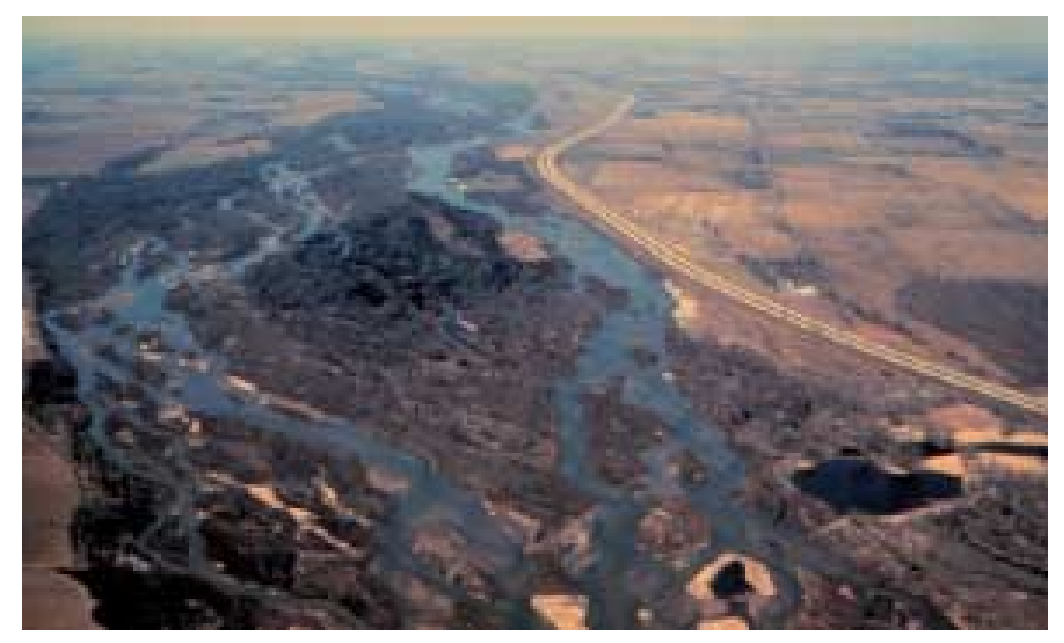

Information regarding the NAWQA Program is available on the Internet via the World Wide Web. You may connect to the NAWQA Home Page using the Universal Resource Locator (URL): http://water.usgs.gov/nawqa/nawqa_home.html 